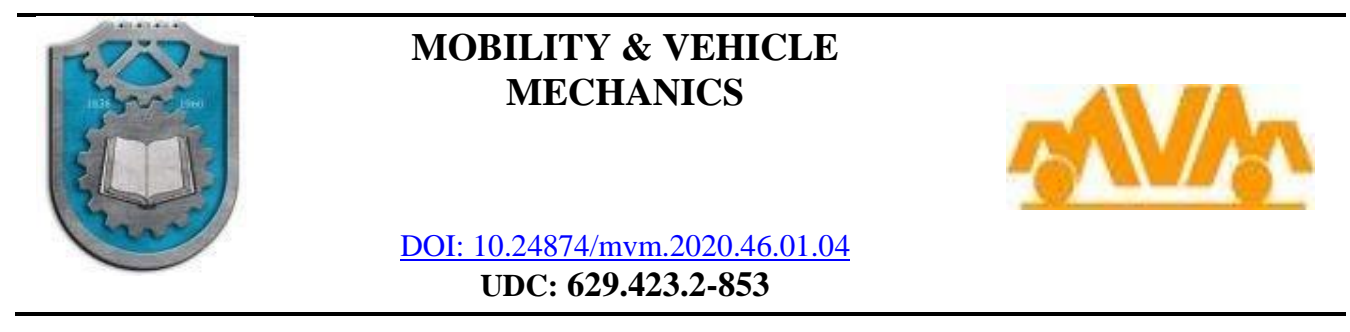

\title{
FUEL CELLS AND ELECTRIC VEHICLES
}

\author{
Miroljub Adžić ${ }^{1 *}$
}

Received in October 2018 Accepted in April 2020

\section{RESEARCH ARTICLE}

\begin{abstract}
The paper is concerned with fuel cell and hydrogen technologies and their application in electric vehicles. Beside positive energy balance effects, these technologies can decrease pollutants and carbon dioxide emissions. Fuel cells and hydrogen are quite mature technologies and already used in transportation systems. There are still drawbacks that prevent wider usage of fuel cell and hydrogen: current costs of electrical vehicles, fuel cells and hydrogen, hydrogen storage, very poor hydrogen infrastructure, lack of public awareness that hydrogen is a safe technology, already developed and applied battery technologies and political issues. Regarding the applicability in light vehicles, proton exchange membrane fuel cells together with hydrogen show good performance. It would not be a surprise that in the future hydrogen might affect the geo-strategy concepts based on fossil fuels.
\end{abstract}

KEY WORDS: fuel cells, electric vehicles, hydrogen

(C) 2020 Published by University of Kragujevac, Faculty of Engineering

${ }^{1}$ Miroljub Adžić, PhD prof., University of Belgrade Faculty of Mechanical Engineering, K. Marije 16, 11000 Beograd, mikce2001@gmail.com (*Corresponding author) 


\section{GORIVE ĆELIJE I ELEKTRIČNA VOZILA}

REZIME: Rad se bavi tehnologijama gorivih ćelija i vodonika i njihovom primenom u električnim vozilima. Pored pozitivnih efekata energetskog balansa, ove tehnologije mogu smanjiti zagađivače i emisiju ugljen-dioksida. Gorive ćelije i vodonik su prilično zrele tehnologije i već se koriste u transpotrnim sistemima. Još uvek postoje nedostaci koji sprečavaju veću upotrebu gorivih ćelija i vodonika: trenutni troškovi električnih vozila, gorivih ćelija i vodonika, skladištenje vodonika, veoma loša infrastruktura za snabdevanje vodonikom, nedostatak znanja javnog mnjenja da je vodonik sigurna tehnologija, već razvijena i primenjena tehnologija baterija i politička pitanja. Što se tiče primene u lakim vozilima, gorive ćelije sa proton-izmenjivom membranom zajedno sa vodonikom pokazuju dobre performanse. Ne bi bilo iznenađujuće da bi u budućnosti vodonik mogao uticati na koncepte geo-strategija zasnovanih na fosilnim gorivima.

KLJUČNE REČI: gorive ćelije, električna vozila, vodonik 


\title{
FUEL CELLS AND ELECTRIC VEHICLES
}

\author{
Miroljub Adžić
}

\section{INTRODUCTION}

The main conclusion of Fuel Cell Seminar in 1992, which was supported by US Department of Energy, Commission of European Communities and Japan Fuel Cell Development Center, was: „Fuel cells represent a technology which could potentially replace internal combustion engines in all areas of ground transportation in the 21 st century" [1]. In the meantime, although never fully supported, fuel cells have reached maturity, side by side with internal combustion engines, when it comes to power performance and reliability. One should keep in mind that these two devices substantially differ: fuel cells deliver electric, while engines deliver mechanical power. It appears that the long waited good news for fuel cells happened in January 2017 at the World Economic Forum in Davos, when thirteen word leading energy, transport and industry companies have launched a global initiative by establishing Hydrogen Council Coalition with the ambition to "Accelerate their significant investment in the development and commercialization of the hydrogen and fuel cell sectors as part of the future energy mix with appropriate policies and supporting schemes." The Coalition founders are Air Liquide, Alstom, Anglo American, BMW GROUP, Daimler, ENGIE, Honda, Hyundai Motor, Kawasaki, Royal Dutch Shell, The Linde Group, Total and Toyota [2]. In one year, a number of other world leading companies joined the Council.

\section{FUEL CELLS}

Fuel cells are electrochemical devices that are capable of directly converting chemical energy of a fuel into electrical energy. Although the fuel cell principle was discovered almost 200 years ago and a practical device is relatively simple, there are still problems not easy to solve and a room to improve the performance. What are the differences between combustion of a fuel or its utilization in a fuel cell? A combustion is a process in which fuel and oxidant are brought into state of a complex mixture of radicals, atoms and molecules that react andrecombine to combustion products. During the combustion process chemical energy of fuel converts into heat and work. Combustion in real devices mainly happens in a turbulent flow regimes. If we speak about gaseous, premixed combustion, depending on the turbulence intensity and scales, combustion may proceed as a distinctive laminar, two dimensional, thin flame front, or as three dimensional processes [3]. Unlike to combustion, fuel and oxidant do not meet as such in fuel cells, Figure 1 . They are physically separated by an electrolyte, a substance that must be an insulator for electrons, good ion conductor and impermeable for gases. Hydrogen, the basic fuel for fuel cells, is ionized to a proton and an electron: $\mathrm{H} \rightarrow \mathrm{H}^{+}+\mathrm{e}^{-}$. The proton is transported through electrolyte to react with oxygen, the electron is picked up by an electrode (anode) and transported into an electric circuit. By transporting ions and electrons electric current is generated and electric work is being done. The energy balance of the process is on the account of chemical energy of fuel which is converted into electrical work and to less extent into heat. There are different types of fuel cells, classified on different grounds, but it is mostly common to be classified by the type of electrolyte. However, the operating principle is similar for all types. For automotive use proton exchange membrane fuel cells (PEMFC) are the best suited. Keeping in mind the aim of this paper, only hydrogen and PEMFC are considered. This will not affect the general thermo and electrochemical analysis of fuel cell operation. A more detailed schematics of a proton exchange membrane fuel cell is shown in Figure 2. The PEMFC electrolyte is a sulfonated tetrafluoroethylene based fluoropolymer-copolymer, in the form of a thin plastic 
membrane. Between the electrode and the electrolyte (membrane) there are two layers: a gas diffusion layer (GDL), which enables diffusion of gases and transport of electrons, and a catalyst layer, a carbon supported platinum catalyst where main reactions take place. The gaseous fuel (hydrogen) continuously flows over the anode while the oxidant (air) over to the cathode. The $\mathrm{H}_{2}$ molecules pass through GDL and adsorb onto the catalyst layer where breaking of the $\mathrm{H}-\mathrm{H}$ bond happens and atomic hydrogen adsorbs onto the surface. In the presence of $\mathrm{H}_{2} \mathrm{O}$ the adsorbed hydrogen desorbs as proton $\left(\mathrm{H}^{+}\right)$while the liberated electron $\left(\mathrm{e}^{-}\right)$is conducted to anode and further into the external electric circuit. The transport of protons $\mathrm{H}^{+}$has to overcome chemical and electrostatic field energy barriers, the sum of which is net energy barrier, as shown in Figure 3. Protons are transported through the electrolyte where at the cathode catalyst layer two protons react with oxygen and with two electrons coming via the closed external electric circle, doing electric work, producing only $\mathrm{H}_{2} \mathrm{O}$ and heat [4-6]. The overall reaction mechanism is complex, still not completely understood. The role of a platinum based catalyst is crucial. It substantially lowers the activation energies of reactions and accelerates the rate controlling steps.

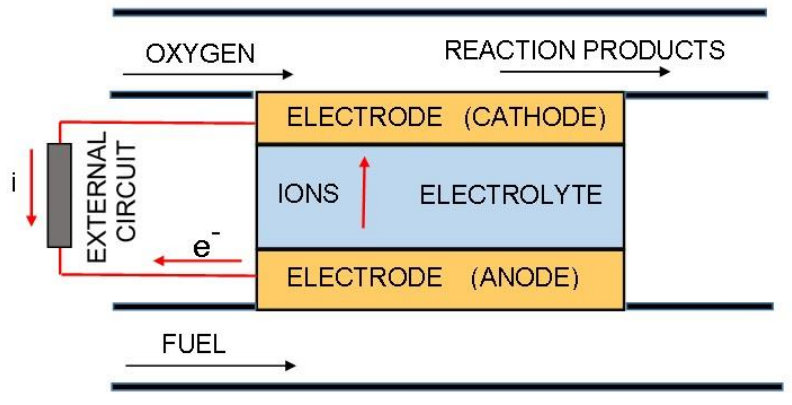

Figure 1. Schematic of fuel cell

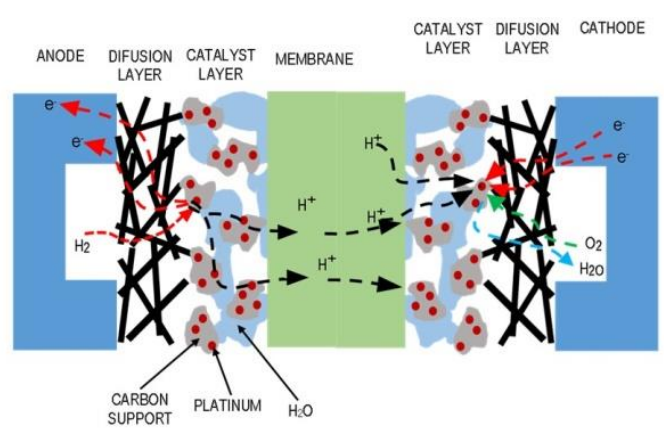

Figure 2. Schematic of the fuel cell process 


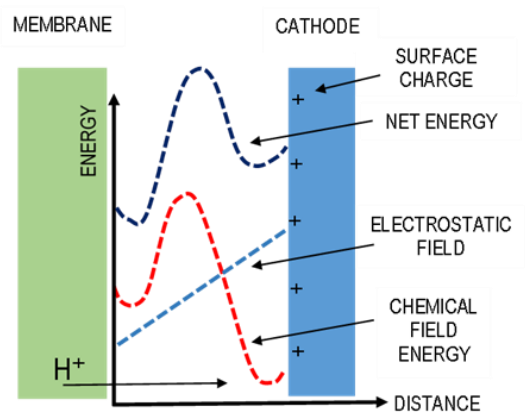

Figure 3. Schematic of fuel cell membrane-cathode energy field

Fuel cells can be fuelled by any fuel, but presence of carbon, sulphur and some other components can pose very serious problem depending on the fuel cell type. For that reason hydrogen is considered the ultimate fuel for fuel cells. One should notice that contrary to combustion, which is a three dimensional process, a fuel cell operates as a surface based process. This is one of the main reasons why combustion can deliver hundreds of megawatts of thermal power per unit volume of combustor while fuel cells are for orders of magnitude less effective.

\subsection{Thermo and Electrochemistry of a Fuel Cell}

We consider a fuel cell a reversible isothermal open thermodynamic system, with steady flow, negligible changes of potential and kinetic energy. By combining the first and the second law of thermodynamics we get

$$
\mathrm{TdS}=\mathrm{dU}+\mathrm{pdV}+\delta \mathrm{A}=\mathrm{dH}+\delta \mathrm{A}, \mathrm{J} / \mathrm{mol}
$$

where $\mathrm{T}$ stands for absolute temperature, $\mathrm{S}$ entropy, $\mathrm{U}$ internal energy, $\mathrm{V}$ volume, A any other work except $\mathrm{pdV}$ and $\mathrm{H}$ enthalpy. From this equation follows that the maximum available work a system can deliver, $\delta \mathrm{A}$, is

$$
\delta \mathrm{A}=\mathrm{Td} S-\mathrm{dH}
$$

If we introduce the Gibbs free energy (available work) function $\Delta \mathrm{G}$ term

$$
\mathrm{dG}=-\delta \mathrm{A}=\mathrm{dH}-\mathrm{TdS}
$$

and if only the electric forces do the work, then the work done by a system is

$$
\Delta \mathrm{A}=-\Delta \mathrm{G}=\text { Eit }
$$

where $\mathrm{E}$ is electric potential (voltage) delivered by a fuel cell, $\mathrm{i}$ is electric current flowing during period of time t. From (4) the electric potential $E$ is

$$
\mathrm{E}=-\Delta \mathrm{G} / \mathrm{it}
$$

The equation (5) shows that a fuel cell potential depends only on change of Gibbs energy, which is a unique characteristic of each fuel-oxidant system. In general, the potential is about $1 \mathrm{~V}$. 
Let us explain the operation of fuel cells fuelled by hydrogen. The overall chemical reaction is

$$
\mathrm{H}_{2}+1 / 2 \mathrm{O}_{2}=\mathrm{H}_{2} \mathrm{O}
$$

The process starts with ionization of a hydrogen molecule

$$
\mathrm{H}_{2}=2 \mathrm{H}^{+}+2 \mathrm{e}^{-}
$$

One mol of hydrogen $\left(6.02310^{23}\right.$ molecules $)$ is ionized to $2 * 6.02310^{23}=12.04610^{23}$ protons and $12.04610^{23}$ electrons. The charge of an electron is $1.60210^{-19} \mathrm{C}$ (coulombs), therefore the total charge q of free electrons is $192970 \mathrm{C} / \mathrm{mol}$. Keeping in mind that electric current is defined as a flow of electric charge $q$ per time, $i=q / t$, we have

$$
\mathrm{E}=-\Delta \mathrm{G} / \text { it }=-\Delta \mathrm{G} / \mathrm{it}=-\Delta \mathrm{G} / \mathrm{q}
$$

As the change of Gibbs energy, $\Delta \mathrm{G}$ for hydrogen-oxygen reaction (at $\mathrm{T}=298 \mathrm{~K}$, atmospheric pressure and water in liquid state) is $-237245 \mathrm{~J} / \mathrm{mole}$, the electric potential of a fuel cell is

$$
E=-\Delta G / q=237245 / 192970=1.229, \mathrm{~J} / \mathrm{C} \text { or V }
$$

We should keep in mind that the value of calculated potential is theoretical one, at electrostatic conditions. Fuel cells appear to deliver electric energy in an elegant and efficient way. In practice a fuel cell faces a number of complex problems. With the onset of electric current the voltage decreases due to the onset of activation polarization (voltage losses by overcoming the activation energy needed to transport ions through the established electro-chemical field at the surfaces of electrodes), ohmic (Joule effect - heat generated by current flow) and mass transport losses (consumption of reactants induces concentration gradients which affect the fuel cell voltage as the supply of reactants is governed by Fick's law of molecular diffusion). Typical voltage and power curves of hydrogen fuelled PEMFC are shown in Figure 4 [7].

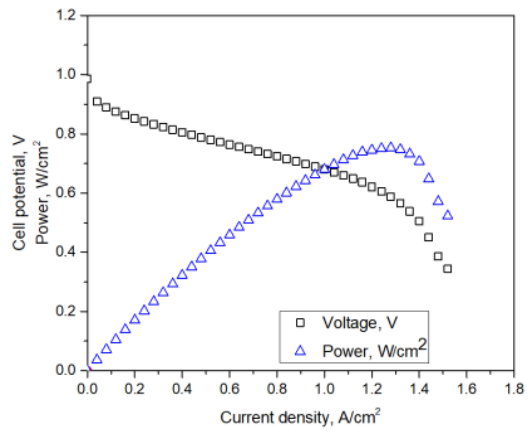

Figure 4. Typical voltage and power curves of an actual PEMFC fuel cell as a function of current density per geometrical unit area of membrane

The decrease of voltage with current are actually losses due to the kinetic effects of polarization activation (needs time to free the electrode surfaces from already occupied sites to take place for adsorption of new ions), ohmic (Joule loses Ri2) and mass transfer losses (Fick's law, $D d c / d x$, decrease of concentration gradient).

The absolute (theoretical) efficiency of a fuel cell $\eta$ is defined as the ratio between maximum available work $\Delta \mathrm{G}$ and the heat of combustion $\Delta \mathrm{H}$ of a fuel 


$$
\eta=\Delta \mathrm{G} / \Delta \mathrm{H}
$$

For hydrogen-oxygen and liquid $\mathrm{H}_{2} \mathrm{O}, \eta=237245 / 285830=0.83$; for water in gaseous state, $\eta=0.945$; for methane and liquid water, $\eta=0.92$. As one can see the absolute efficiency depends only on fuel used, not on fuel cell type. In practice the efficiency is significantly lower. It is interesting to compare absolute (theoretical) efficiency of fuel cell hydrogen fuelled, and the Carnot cycle efficiency, Figure 5.

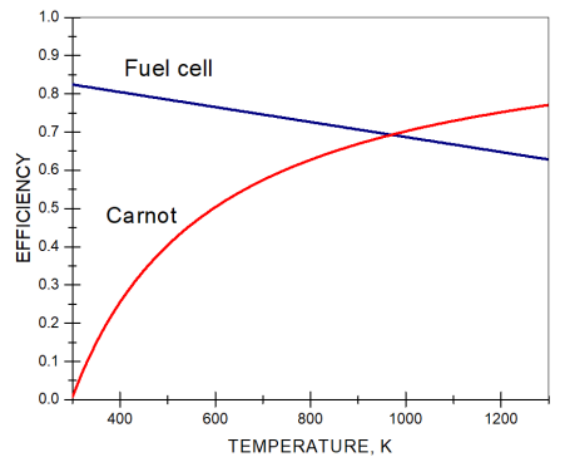

Figure 5. Comparison of fuel cell and Carnot cycle efficiency at lower temperature 298 K, [11]

Only at high temperatures over about $1000 \mathrm{~K}$ Carnot efficiency becomes superior to that of fuel cells. Keeping in mind that PEMFC operates at temperatures of about $100 \mathrm{~K}$, its superiority over efficiency of Carnot is evident.

The electrical efficiency $\eta_{\mathrm{e}}$ of a fuel cell is defined as the ratio of electrical power generated and the power of combustion based on the upper heating value of fuel used

$$
\eta_{\mathrm{e}}=\mathrm{Ei} / \Delta \mathrm{H} \dot{m}
$$

where $\Delta \mathrm{H}$ is the higher heat of combustion of fuel and $\dot{\mathrm{m}}$ is the fuel mass flow rate $(\mathrm{kg} / \mathrm{s})$. The electrical efficiency of fuel cell stacks can reach $0.55-0.60$ when hydrogen fueled.

As just shown, fuel cells are low voltage DC devices with the voltage output of about 1 Volt. For practical purposes, in order to increase the voltage and power, individual fuel cells are stacked in series, stacks, Fig. 6. A stack compared with unit cell is generally far more difficult to operate, because of more complicated mass, heat, liquid water and electric current management resulting in the decrease of efficiency, reliability and life of fuel cells.

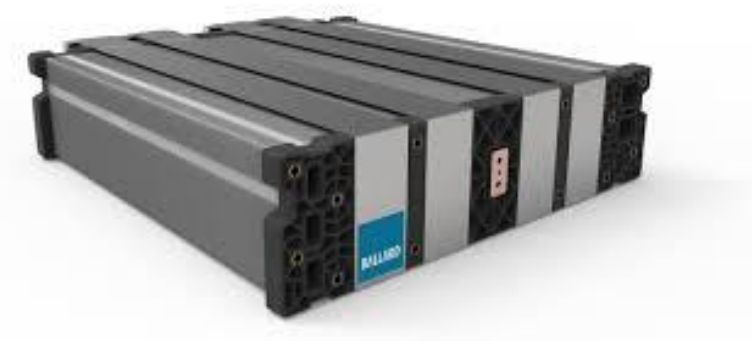

Figure 6. Ballard fuel cell stack 
The theoretical effects of temperature and pressure on fuel cell voltage can be deduced from eq. 8 where $E=-\Delta G / q$ and from $\delta(\Delta G) / \delta p=\Delta V$, where $\Delta V$ is the volume change of particular reaction. One should keep in mind that with the increase of temperature, $\Delta G$ increases (becomes less negative) but that affects the voltage of the order of millivolts, while the change of volume, e.g. for hydrogen fuel cell, is large, therefore the effect of pressure on voltage is evident. Nevertheless, in practice, these effects are much more complicated due to the effects of stack design, size, operating temperature and pressure, heat and mass transfer management and others.

It is worth noting that an electric battery is also an electrochemical electric energy source, but contrary to a fuel cell that can theoretically run for any period of time, as long as fuel and oxygen are supplied, a battery is just energy storage with limited capacity.

\subsection{Fuel Cell Performance}

The technology of PEMFCs is fully matured and in some elements better or in line with other systems like internal combustion engines and batteries. It is a question of performance, cost, primary energy sources, infrastructure and a policy to what extent PEMFC will be used in electric vehicles [7-14]. The brief visual comparison of some significant performance, based on the status in 2015/2017 are given in Figures 7-10 and Table 1. (The performance of fuel cells, motors and batteries, used in this paper, are the manufacturers' published data, as given). The efficiency of PEMFC (ratio between FC electric power and the chemical energy flow) including expectations in the future [5] and the last achievements in thermal efficiency of the Toyota gasoline engine is shown in Figure 7. The supremacy of fuel cell is impressive. Regarding mass to power ratio, life and startup time, Table 1 [5], as we can see, in next 10-15 years the mass to power ratio of PEMFC is planned to decrease three times, the life time to increase almost three times, and startup time to decrease for an order of magnitude. Even now the startup time is quite acceptable for transportation vehicles, two minutes. Comparison of mass to power ratio of PEMFC, internal combustion engine, electric drive and turboprop, as a function of power, is shown in Figures 8 and 9 [11].

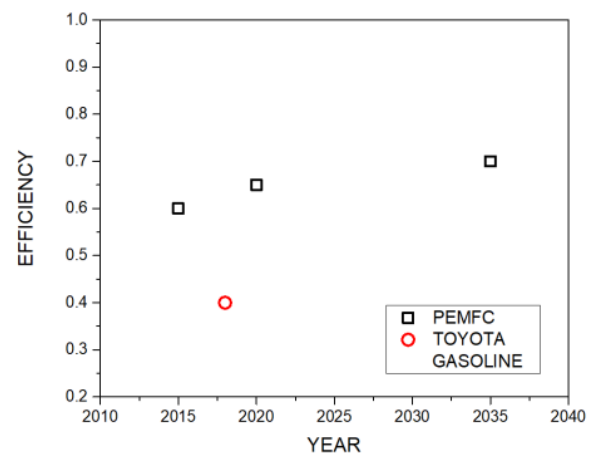

Figure 7. Efficiency of PEMFC and Toyota gasoline engine (2018) 
Table 1. Performance indicators of PEMFC

\begin{tabular}{|c|c|c|c|}
\hline PEMFC fuel cell & $\begin{array}{c}\text { Mass / Power } \\
\text { ratio, } \mathrm{kg} / \mathrm{kW}\end{array}$ & Lifetime, $\mathrm{h}$ & $\begin{array}{c}\text { Startup time, for a stack, } \\
\text { seconds }\end{array}$ \\
\hline Short term (5-10 years) & $0.5-0.2$ & 20000 & 120 \\
\hline $\begin{array}{c}\text { Mid-term }(10 \text { to } 15 \\
\text { years })\end{array}$ & $0.25-0.17$ & 40000 & 60 \\
\hline Long term ( >>15 years) & $<0.15$ & 50000 & 10 \\
\hline
\end{tabular}

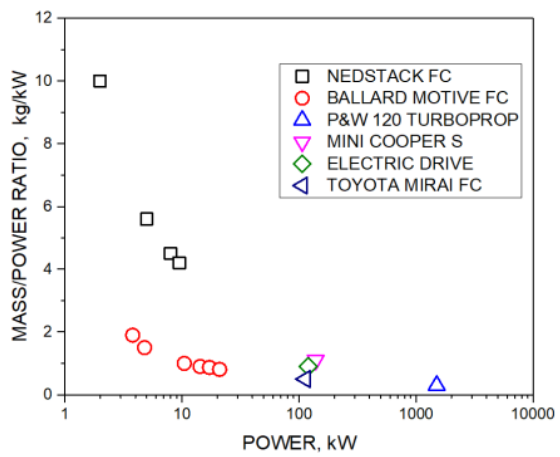

Figure 8. Mass to power ratio of PEMFCs (Nedstack, Ballard), internal combustion engine (Mini Cooper S-BMW), electric drive and turboprop engine (Pratt and Whitney 120)

As expected, the specific mass decreases with the power increase. It is worth noting that some of the Ballard fuel cells are at least as good as internal combustion engines and electro drives, but the recent efforts of Toyota resulted in very impressive results. Toyota managed the technological leap in a couple of years. The mass to power and volumetric power ratios of the Toyota PEMFC are the same as modern internal combustion engines and electric drives. In conclusion: the PEMFC mass-volume-power performance has reached the level of internal combustion engines and electric drives.

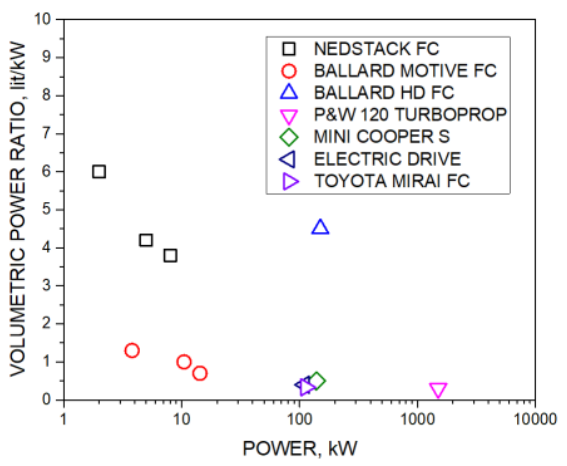

Figure 9. Volume to power ratio of PEMFC (Nedstack, Ballard), internal combustion engine (Mini Cooper S-BMW), electric drive and turbo-shaft engine (Pratt and Whitney 120) 
The cost of PEMFC system primarily depends on number of units produced. Prediction of PEMFC cost in 2017 is given in Figure 10 [5]. It is interesting that the effect of year of production is rather small. It is expected that in 2025 the cost will be about $10 \%$ lower. At the moment the Toyota fuel stack cost is about $\$ 11,000$ for annual production of 3,000 units. It is expected that with annual production of 30,000 the cost will drop to $\$ 8,000$.

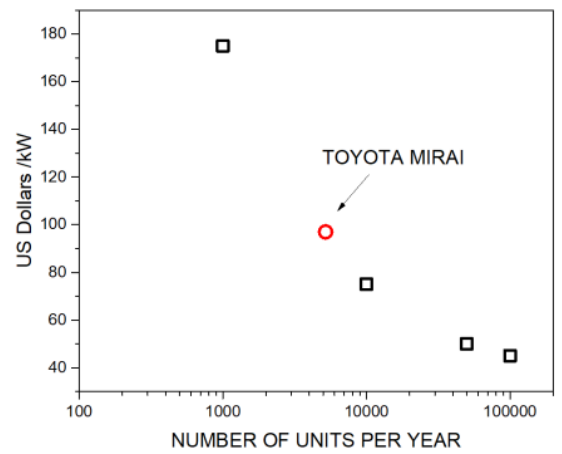

Figure 10. An $80 \mathrm{~kW}$ fuel cell power system for transportation prediction (2015), as a function of number of sold units

\section{HYDROGEN}

A chemical energy source to run a fuel cell can be any fuel, but hydrogen is far the most appropriate. Some important properties of hydrogen are given in Table 2 [5].

Table 2. Properties of hydrogen

\begin{tabular}{|c|c|}
\hline Gaseous hydrogen & \\
\hline Density $\left(\mathrm{kg} / \mathrm{m}^{3}\right.$ at $273 \mathrm{~K}, 1.013$ bar $)$ & 0.089 \\
\hline Lower heating value $(\mathrm{MJ} / \mathrm{kg})$ & 120.0 \\
\hline Lower heating value $\left(\mathrm{MJ} / \mathrm{m}^{3}\right)$ & 10.68 \\
\hline Stoichiometric air fuel ratio $\left(\mathrm{m}^{3} / \mathrm{m}^{3}\right)$ & 2.38 \\
\hline Liquid hydrogen & \\
\hline Density $\left(\mathrm{kg} / \mathrm{m}^{3}\right.$ at 1.013 bar and boiling temp. $\left.20.3 \mathrm{~K}\right)$ & 70.9 \\
\hline Critical temperature $(\mathrm{K})$ & 33 \\
\hline
\end{tabular}

Although the main constituent of space, free hydrogen is scarce in our environment and has to be produced. About $96 \%$ of world hydrogen production is via fossil fuels, about $50 \%$ from natural gas, $30 \%$ from oil and $18 \%$ from coal, by different technologies. It should be stressed that the production of one $\mathrm{kg}$ of hydrogen from fossil fuels evolves about $11 \mathrm{~kg}$ of $\mathrm{CO}_{2}$. New important technologies like the microorganisms and algae production of hydrogen from biomass with decentralized production from biomass become available. Most of hydrogen is used as raw material in fertilizer, chemical, oil, metal, food, pharmaceutical and glass industries. World consumption of hydrogen in 2016 was about 85 million tons, growing steadily. New developments are in the areas of innovative water electrolysers that can provide low price hydrogen production based on polymer-membrane 
and solid oxide fuel cell technologies. The attractive idea to get hydrogen from natural gas reforming and use in low temperature fuel cells like PEMFC has serious drawback: platinum based electrode catalysts can be poisoned by impurities, such as carbon monoxide, which is a natural constituent of the reformate. Besides, the very concept of fuel cells' low impact on the environment is jeopardized by high $\mathrm{CO}_{2}$ emission when using hydrogen produced from fossil fuels. Hydrogen for fuel cells ought to be produced by lower impact systems, e.g., wind, solar or nuclear energy water electrolysis. At a glance, it does not look reasonable to produce electric energy by any method, use it to get hydrogen by water electrolysis and use it in a fuel cell to get electric energy again. The point is the energy accumulation effect of hydrogen storage that can help solving intermittency, fast fluctuations and surplus of wind and solar energies which can disrupt the electric grid balance and planning, as power plants cannot quickly adjust their production and balance total energy supply and demand. We have recently witnessed unimaginable situation when German producers of electric power paid some consumers to switch on and use electric utilities. And of course, the intentional production of hydrogen to be used in fuel cells and other purposes makes clear sense. One should also notice as well a very important fact that by this approach the total water balance in nature is zero. The main problems when using hydrogen in fuel cells or other energy production devices are low volumetric heat of combustion, rather poor storage properties, lack of infrastructure, cost, public stereotype that hydrogen is dangerous and lack of internationally homogenized standards and regulations.

Germany could be a good example of correlation between impressive increase of production of solar and wind based electric energy and the support of electric vehicles, hydrogen and fuel cells, Figure 11 [15]. The situation in Japan is even more positive towards use of hydrogen.

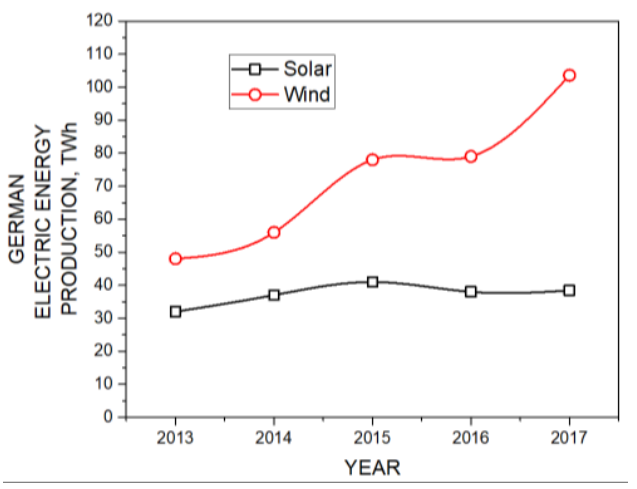

Figure 11. Wind and solar electric energy production in Germany during last five years

\subsection{Hydrogen Storage}

There is a number of hydrogen storage methods. From compressed gas cylinders, low temperature high pressure liquid, to adsorption over new exotic materials. For passenger vehicles the standard compressed hydrogen pressure is $70 \mathrm{MPa}$, while $35 \mathrm{MPa}$ is for light and heavy trucks. There have been many efforts on hydrogen storage optimization, development of pressurized cylinders, valves, pressure regulators, pressure and temperature sensors and also high efficiency hydrogen compressors. Beside classical systems, the innovative approach uses electrochemical compressors with efficiency of $4 \mathrm{kWh} / \mathrm{kgH}_{2}$ at 70 $\mathrm{MPa}$. Table 3 presents some new storage systems [5]. 
Table 3. New hydrogen storage systems

\begin{tabular}{|c|c|}
\hline Materials & Energy storage \\
\hline Nanotubes physisorption (high pressure, low temperature) & $13.2 \mathrm{MJ} / \mathrm{kg}$ \\
\hline Nanotubes & $6 \mathrm{MJ} / \mathrm{l}$ \\
\hline Graphene chemisorption & $9.6 \mathrm{MJ} / \mathrm{kg}$ \\
\hline Polymer matrix & $10.8 \mathrm{MJ} / \mathrm{kg}$ \\
\hline Hollow $\mathrm{Li}_{20} \mathrm{~B}_{60}$ cage & $9.6 \mathrm{MJ} / \mathrm{kg}$ \\
\hline
\end{tabular}

The serious drawbacks of the new storage systems are as follows:

- Only laboratory proved

- Expensive

- High pressure, low temperature needed

- Low rates of sorption/desorption.

Hydrogen in a liquid state was abandoned, except for rocket propulsion, due to extreme conditions to fulfil very low temperature of $20 \mathrm{~K}$ and high pressure. The energy storage of hydrogen storage systems capacities by mass and volume are shown in Figure 12 [11].

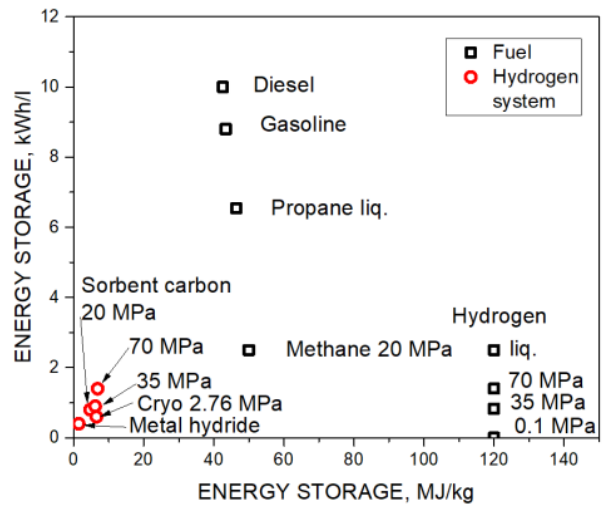

Figure 12. Energy storage capacities by mass and volume of fuels, hydrogen and hydrogen storage systems

It can be seen that the oil based fuels make good compromise between volumetric and mass energy storage, hydrogen has excellent mass but poor volumetric capacities. In general, hydrogen storage systems have low storage capacities either by mass or volume. About the hydrogen cost. Due to the political commitment and hydrogen technology production developments, the hydrogen price shows constant decrease and it is expected that in the next decade the price will be close to the price of liquid hydrocarbon fuels for transport, see Figure 13 [5]. The EU goal is the retail price at filing stations of $5.5 € / \mathrm{kg}$, or $0.046 € / \mathrm{MJ}$, thus approaching the $95 \mathrm{RON}$ gasoline retail price in Germany of $1.49 € / 1$ or $0.044 € / \mathrm{MJ}$, in September 2018. The retail price of hydrogen in August 2018 in Japan was $0.064 € / \mathrm{MJ}$. 


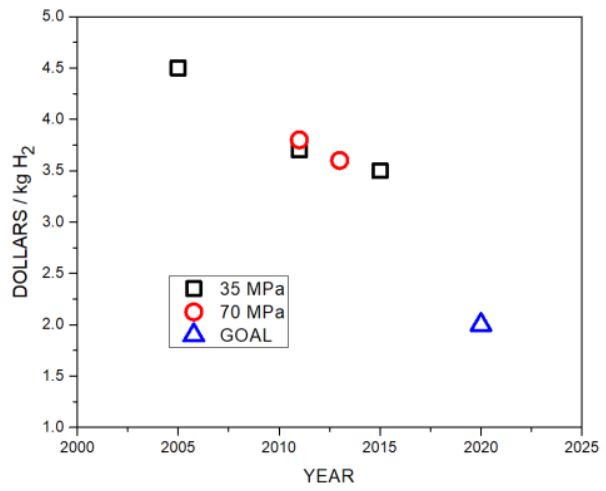

Figure 13. Centralized mass production of hydrogen, price prediction in USA for two standard storage pressures

The main obstacle for wider use of fuel cell vehicles is the lack of hydrogen infrastructure, number and distribution of hydrogen filling stations. In June 2018 there were less than 300 hydrogen filling stations worldwide [5]: 93 in Japan, 44 Germany, 39 USA, 12 South Korea, 11 England, 10 Denmark, 9 Norway, 9 in France and less than that in other countries. The good side is that hydrogen tank filling up is fast. It takes a couple of minutes.

\section{ELECTRIC BATTERIES}

Electric batteries is proven and common energy storage technology. They are easy to use and operate. The drawbacks are low specific storage capaticies per mass and volume, price, and charging performance: either it takes hours or high power charging systems have to be used. Besides, fast charging induces stresses and can lower the discharge capacity of a battery. At the moment two types of batteries are of main interest for electric vehicles: nickel-metal hydride (Ni-MH) and lithium-ion (Li-ion) batteries. The general performance indicators of electric batteries are presented in Table 4 [5]. As one can see, the mass to power ratio of batteries is planned to decrease three to six times, the lifetime is expected to reach over 1500 cycles in next 15 years.

Table 4. Performance indicators of batteries

\begin{tabular}{|c|c|c|c|c|}
\hline Batteries & $\begin{array}{c}\text { Mass/energy } \\
\text { stored ratio, } \\
\mathrm{kg} / \mathrm{kWh}\end{array}$ & $\begin{array}{c}\text { Gasoline } \\
\mathrm{kg} / \mathrm{kWh}\end{array}$ & $\begin{array}{c}\text { Hydrogen, } \mathrm{kg} / \mathrm{kWh} \\
\text { Toyota Mirai, 700 bar } \\
\text { cylinder }\end{array}$ & $\begin{array}{c}\text { Lifetime, } \\
\text { cycles }\end{array}$ \\
\hline $\begin{array}{c}\text { Short term } \\
\text { (5-10 years })\end{array}$ & $6-3$ & & & \\
\hline $\begin{array}{c}\text { Mid-term } \\
\text { (10 to } 15 \text { years })\end{array}$ & $3-2$ & \multirow{2}{*}{0.08} & 0.53 & $\begin{array}{c}>1500 \\
\text { cycles; } \\
\text { capacity } \\
\text { drop } \\
<30 \%\end{array}$ \\
\hline $\begin{array}{c}\text { Long term } \\
(>>15 \text { years })\end{array}$ & $2-1$ & & & \\
\hline
\end{tabular}

The capital cost for Li-ion battery pack per energy stored was about $400 \mathrm{US} \$ / \mathrm{kWh}$, in 2015, with tendency to drop. In 2017 it was about $250 \$ / \mathrm{kWh}$. Further drop is expected to slow down with the expected cots in 2030 of about $100 \$ / \mathrm{kWh}$, Figure 14 [5]. 


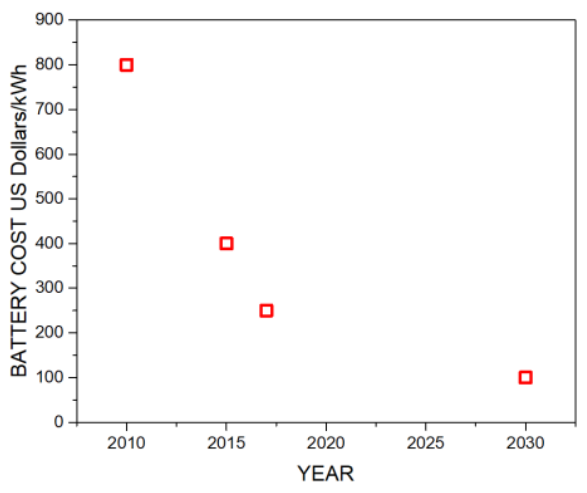

Figure 14. Electric battery cost

\section{ELECTRIC VEHICLES}

The concept of an electric vehicle is more than 200 years old. Electric vehicles have had ups and downs throughout the history. The first serious success in modern era, 20 years ago, comes from Toyota Prius hybrid electric vehicle equipped with nickel metal hydride battery. Later comes Tesla motors, and now there is practically no major car company without an electric vehicle in its production program. Regarding the propulsion systems, there is a steady progress in battery technology. The lithium-ion batteries have bloomed in last two decades. Electric motors and components have also been significantly improved. Also, the mass, volume, power, reliability, life of fuel cell. The electric propulsion interest spreads also to air traffic, (major manufacturers Boeing and Airbus), marine, and transportation in general. The plug-in, plug-in hybrid, fuel cell vehicle technologies have been launched. Public electric vehicle chargers have been installed worldwide. The electric vehicle cost decreased and the environment has become much more supportive: free electric charging, free parking places, open yellow lanes, open access to otherwise forbidden areas in city centers and others. Although the drawbacks are serious, mass to storage ratio, low charging rates and cost, electric vehicles have become commercialized from all major and some specialized manufacturers. The variety and combinations of propulsion systems, internal combustion engines, batteries, fuel cells, controls, fuels, fuel storage, drive components, energy management, materials, improvements and breakthroughs, costs and others is tremendous and very complex, making overall comparison of different types of vehicles difficult and questionable. Having that in mind and the aim of this paper to deliver a limited overview of fuel cell and hydrogen technologies and electric vehicles, this paper compares the cost of similar performance vehicles with different power systems manufactured by the same manufacturer, in this case Toyota, as an indicator of the technologies prospective, Figures 15-17 and Table 5. 


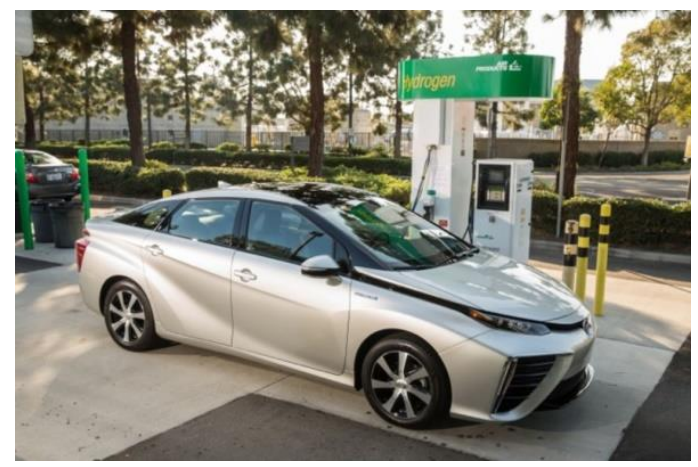

Figure 15. Toyota Mirai and hydrogen filling station

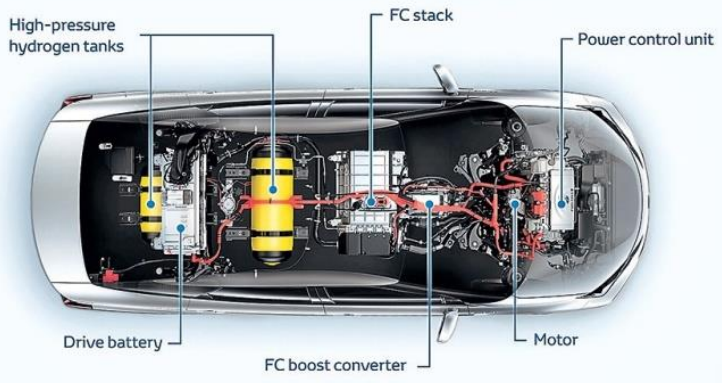

Figure 16. Toyota Mirai main components

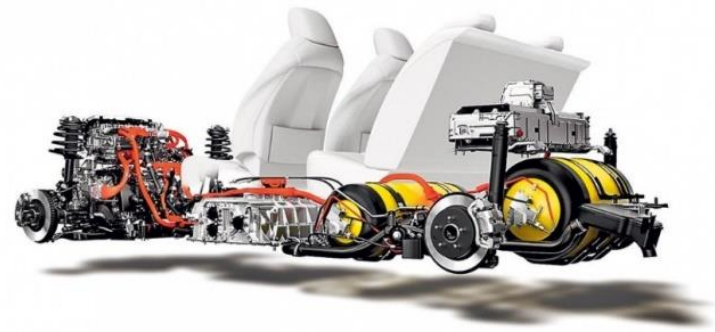

Figure 17. Toyota Mirai powertrain

The Toyota Mirai is a midsize luxury 4 door sedan car. The powertrain consists of $113 \mathrm{~kW}$, $335 \mathrm{Nm}$ electric motor, PEMF fuel cell (370 cells) with maximum power output $114 \mathrm{~kW}$, $0.50 \mathrm{~kg} / \mathrm{kW}, 0.32 \mathrm{l} / \mathrm{kW}$, two 70 Pa pressure hydrogen cylinders with total volume of 122.41 and $84 \mathrm{~kg}$ mass, hydrogen storage of $4.8 \mathrm{~kg}$ or $160 \mathrm{kWh}, 1.6 \mathrm{kWh}$ nickel-metal hydride battery nominal voltage $244 \mathrm{~V}$, capacity $6.5 \mathrm{Ah}$, the vehicle kerb weight is $1,850 \mathrm{~kg}$, range about $500 \mathrm{~km}$ (planned to reach $1000 \mathrm{~km}$ in 2025 !), max speed $178 \mathrm{~km} / \mathrm{h}$, acceleration 0 $100 \mathrm{~km} / \mathrm{h}$ in 9.6 seconds, refueling time 3-5 minutes. The battery assists fuel cell stack 
during acceleration and stores recovered energy during deceleration. The Mirai fuel cell emission is water vapour, cost on the road $\$ 57,500$.

Table 5. Cost of Toyota vehicles

\begin{tabular}{|c|c|}
\hline Type & Cost on the road \$ \\
\hline Avensis - (internal combustion engine; gasoline) & 30.200 \\
\hline Prius Hybrid - (battery and internal combustion engine; gasoline) & 34.800 \\
\hline Prius Plug-in Hybrid - (battery and internal combustion engine; gasoline) & $40.500^{1}$ \\
\hline Mirai - (fuel cell and battery; hydrogen) & $57.500^{1}$ \\
\hline
\end{tabular}

${ }^{1}$ Total sales of Prius plug-in hybrid was about 128,000 and 5,300 Mirai vehicles in 2017

Compared with the similar performance Toyota classical and electrical cars, Table 5, Mirai is expensive. With rise of production units, the cost is expected to decrease. An analysis shows that the cost of Mirai fuel cell of $\$ 11,000$ could drop to $\$ 8,000$ with increased production. Mirai is a hydrogen fuelled environment's best friend, which is an expensive position. Mirai is not a prestige car like Tesla $S$, a must for rich people, a matter of prestige, but a product of responsible national strategy policy, and vision of national future.

\section{CONCLUSIONS}

- Fuel cells and hydrogen are matured technologies of equal performance (power, mass, volume, reliability, life) with internal combustion engines and electric drives, and already used for propulsion of vehicles.

- Fuel cells are superior to internal combustion engines regarding efficiency. When fuelled by hydrogen, fuel cells have excellent pollution and $\mathrm{CO}_{2}$ emission performance.

- The main obstacles for wider usage are cost, hydrogen price and undeveloped hydrogen infrastructure.

- Breakthroughs in fuel cell and battery technologies are possible and expected which is not the case with hydrogen storage technologies.

- The cases of Germany and particularly Japan, show signs of accelerated and more aggressive utilization of hydrogen, meaning changes in strategy of national energy and geostrategic policies in the coming decades.

- Only time will tell what vehicle propulsion systems will prevail in the future.

\section{REFERENCES}

[1] The 1992 Fuel Cell Seminar, Tucson USA, 1992.

[2] Hydrogen C.: Available from: http://hydrogencouncil.com/, Accessed 25.06.2018.

[3] Mahjoub, M. A., Milivojević, A., Adžić, V., Živković, M., Fotev, V, Adžić, M.: "Numerical Analysis of Lean Premixed Combustor Fueled by Propane-Hydrogen Mixture", Thermal Science, Vol. 21, No. 6A, pp 2593-2602, 2017.

[4] Fuel Cell Handbook, EG and G Technical Services, Morgantown, DOE, 2014.

[5] US Dept. of Energy, Energy Efficiency and Renewable Energy, 2017.

[6] Internationa Energy Agency, Hydrogen Production and Storage, OECD, Paris, 2006.

[7] Adzic, M., Fotev, V., Miivojevic, A., Adzic, V.: in the FP7, "Efficient Use of Resources in Energy Converting Applications - PEMFC project", EURECA 20122015. 
[8] Alaswad, A., Baroutaji, A., Achour, H., Carton, J.: "Developments in fuel cell technologies in the transport sector", International Journal of Hydrogen Energy, Vol. 41, Issue 37, 2016, pp 16499-16508.

[9] Pettersson, L., Westerholm, R.: "State of the art of multi-fuel reformers for fuel cell vehicles: problem identification and research needs", International Journal of Hydrogen Energy, Vol. 26, Issue 3, 2001, pp 243-264.

[10] Wang, Y, Dai, K., You, H., Gao, M.: "Research on the design of hydrogen supply system of $70 \mathrm{MPa}$ hydrogen storage cylinder for vehicles", International Journal of Hydrogen Energy, Available online, September 2018.

[11] Adzic, M.: "Hydrogen and Fuel Cells for Aircraft Propulsion", Airbus Meeting, Munich, 2015.

[12] Alavi, F., Lee, E., de Wouw, N., de Schutter, B., Lukszo, Z.: "Fuel cell cars in a microgrid for synergies between hydrogen and electricity networks" Applied Energy Journal, Vol. 192, 2017, pp 296-304.

[13] Trade car view, Available from: https://www.tradecarview.com/specifications/toyota/, Accessed 25.06.2018.

[14] Simons, A., Bauer, C.: "The production and end-of-life processes for current and future proton exchange membrane fuel cell (PEMFC)", Applied Energy Journal, Vol. 157, 2015, pp 884-896.

[15] Eurostat,https://ec.europa.eu/Eurostat. 